\title{
Research on the Interaction between Water Resources Overall Planning and Spatial Planning
}

\author{
Jingshu Chen, Shanghai Tongji Urban Planning \& Design Institute Co., Ltd., China \\ Xu Liu, Shanghai Tongji Urban Planning \& Design Institute Co., Ltd., China
}

\begin{abstract}
This study recognizes the urgency of water problems and the importance of water as the basis for development. Focusing on the study of the interactive influence of spatial planning and water resources, we explore how to reflect the dynamic changes of water resources in spatial planning, and explore strategies that water resilient cities can adopt in spatial planning..
\end{abstract}

\section{Keywords}

water resilience, water resources coordination, spatial planning, resilient flood-bearing, flood control system,

\section{Research Background}

With the intensification of global climate change, many countries and regions in the world are facing problems such as water shortages, water environmental pollution, and frequent floods.

We can no longer solve the current increasingly complex water problems while just do research focus in the field of water. More attention has been paid to the interactive relationship between urban and rural spatial development and water system changes. The time and space fluctuation risk of water resources brings more challenges to the traditional spatial development model of cities. Strengthening the research and application of technical methods for water resources coordination at the spatial planning level is an important part of ensuring the sustainability of water resources and urban development. ${ }^{[1-3]}$

\section{Overview of the research area and technical methods}

This research takes a small city in East China where water shortage and flooding coexist as a case, relying on 35 technology (Remote sensing、Geography information systems、Global positioning systems), focusing on the two aspects : urban and rural water security and mitigation of floods.

Through the watershed climate and hydrological characteristic model and the spatial data mining of the urban and rural spatial distribution, and through the visual expression, we try to find the key contradictions in the water resource and urban development. Such as the environmental damage of the water source, insufficient water reserve, low water use efficiency, unbalanced water use structure, lack of storage space, and narrow flood control channels. And put forward a targeted spatial planning strategy.

In terms of urban flood control, a flood-prone disaster evaluation model is constructed to identify floodrisk areas. According to the city's ability and characteristics to deal with floods, with the goal of "safely resisting floods and being safe in floods", the city's security defense and disaster resilience will be improved. Propose measures to prevent floods and disasters that should be implemented, including improving urban flood control systems, building engineering facilities and resilient flood-bearing facilities, 
and establishing a coordinated management mechanism for river basin flood control. It is hoped that possible disaster losses will be minimized.

\section{Balanced and healthy development of water resources based on bottom- line constraints}

\subsection{Scientifically check the size of urban population to ensure the balance of water supply}

Based on the area's multi-year average available water resources and per capita consumption, the upper limit of the population that can be carried by water resources can be calculated, so as to demonstrate the future population size of the city. At the same time, the temporal and spatial changes in the amount of water resources should be considered. Progressive types such as the improvement of water resources utilization rate brought about by urban water conservancy construction; the decrease of water consumption in a water-saving society. Abrupt types such as changes in precipitation caused by overall regional climate change; adjustments in the utilization and distribution of water resources in the upper and lower reaches of the basin, or cross-regional water supply. In addition, the check of the amount of water resources and population should be refined to smaller units to study the spatial distribution of water resources and the spatial distribution of urban water demand to avoid water overload. ${ }^{[4-6 !}$

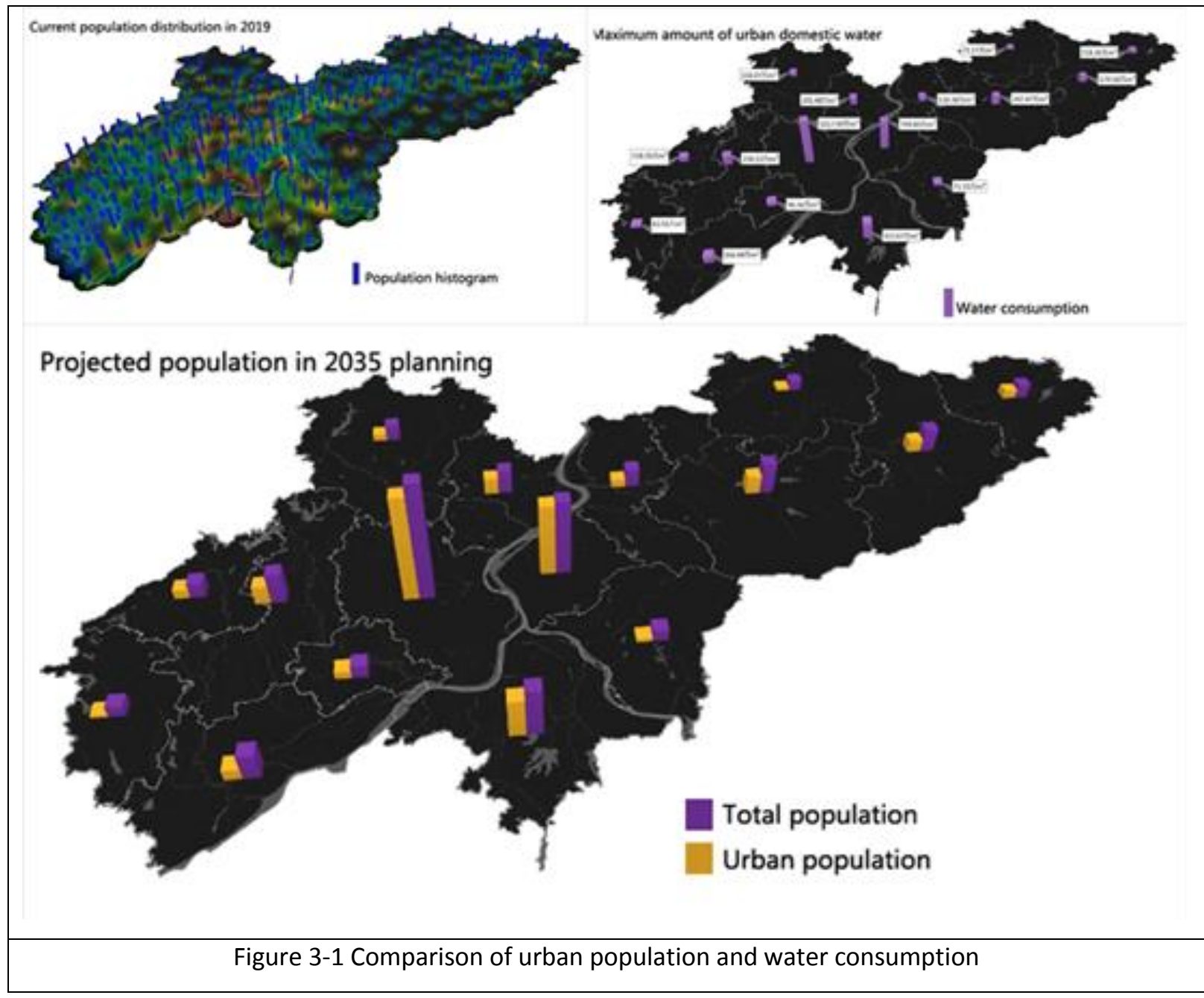

Source: self-painted by the author 


\subsection{Promote the strategic transformation of urban industries and optimize the use of}

\section{water resources}

Study the status of regional water resources and water environment, and evaluate the water health of the current development of the city under the premise of the three red lines of total resources, efficiency control and pollution limitation. For areas that reach the upper limit of pollution, strictly restrict related pollution-type industries and strengthen water pollution prevention and control.

Guide the transformation and upgrading of industrial structure. Adjust the industrial structure and eliminate backward production capacity that does not have the advantages of energy and environmental protection, such as restricting high water-consuming industries such as textiles and cement that the city originally relied on. Strict environmental access and establish a monitoring and evaluation system for water resources and water environment carrying capacity. Optimize the urban spatial layout, and strictly control the development of high water consumption and high pollution industries in areas where water is scarce or the water environment is vulnerable. Promote recycling development and increase the rate of industrial reuse of water. ${ }^{[71}$

Promote the development of water-saving agriculture. Adjust the structure of agricultural water use and optimize the structure of agricultural planting. Check the regional water resources carrying capacity and natural social conditions, and optimize the agricultural industry. Improve project water-saving measures and develop green water-saving agriculture.

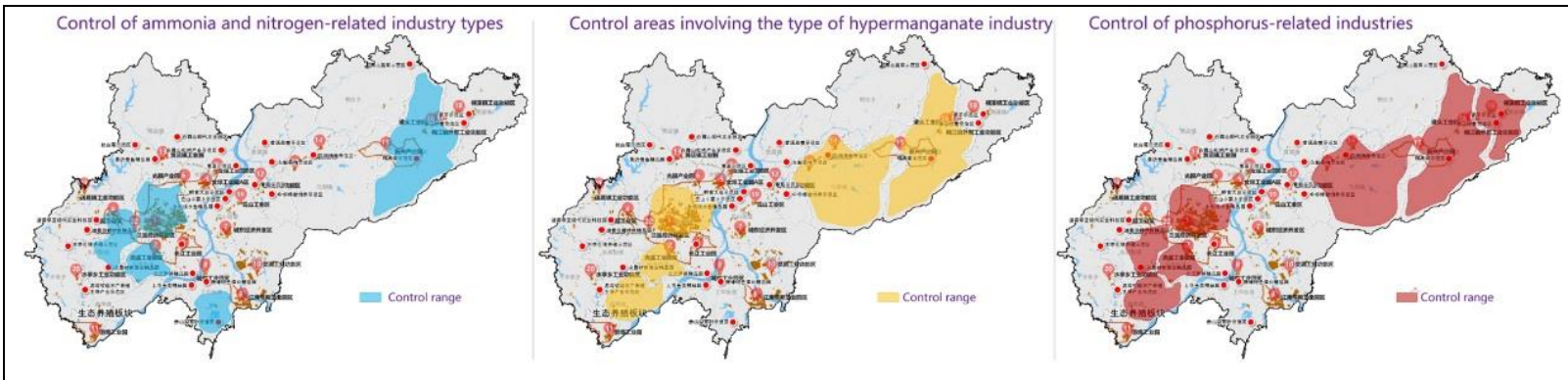

Figure 3-2Negative list of industry types

Source: self-painted by the author

\subsection{Multi-means to ensure stable urban water sources and stable water supply}

Combined with the analysis of urban water demand, calculate the urban and rural water gap supported by the current water supply capacity. For resource-poor water-scarce areas, first of all, it is necessary to actively promote the exploitation of water resources potential. Speed up the feasibility study of new water sources in the medium and long term. Start in advance the protection of water sources, environmental restoration and construction control of new water sources. Strengthen the protection and construction of rural water sources. Continue to promote rural drinking water pipe network transformation and water quality improvement, and remediate small water source projects such as mountain ponds and catch basins.

At the same time, it actively strengthens external linkages and strives for cross-regional diversion of water from areas with relatively rich water resources to resolve the plight of high-quality water shortages. As the basic guarantee of people's lives, water must adhere to the bottom line thinking, increase the guarantee rate of water resources in the region as much as possible, and maintain the stability of water supply. 


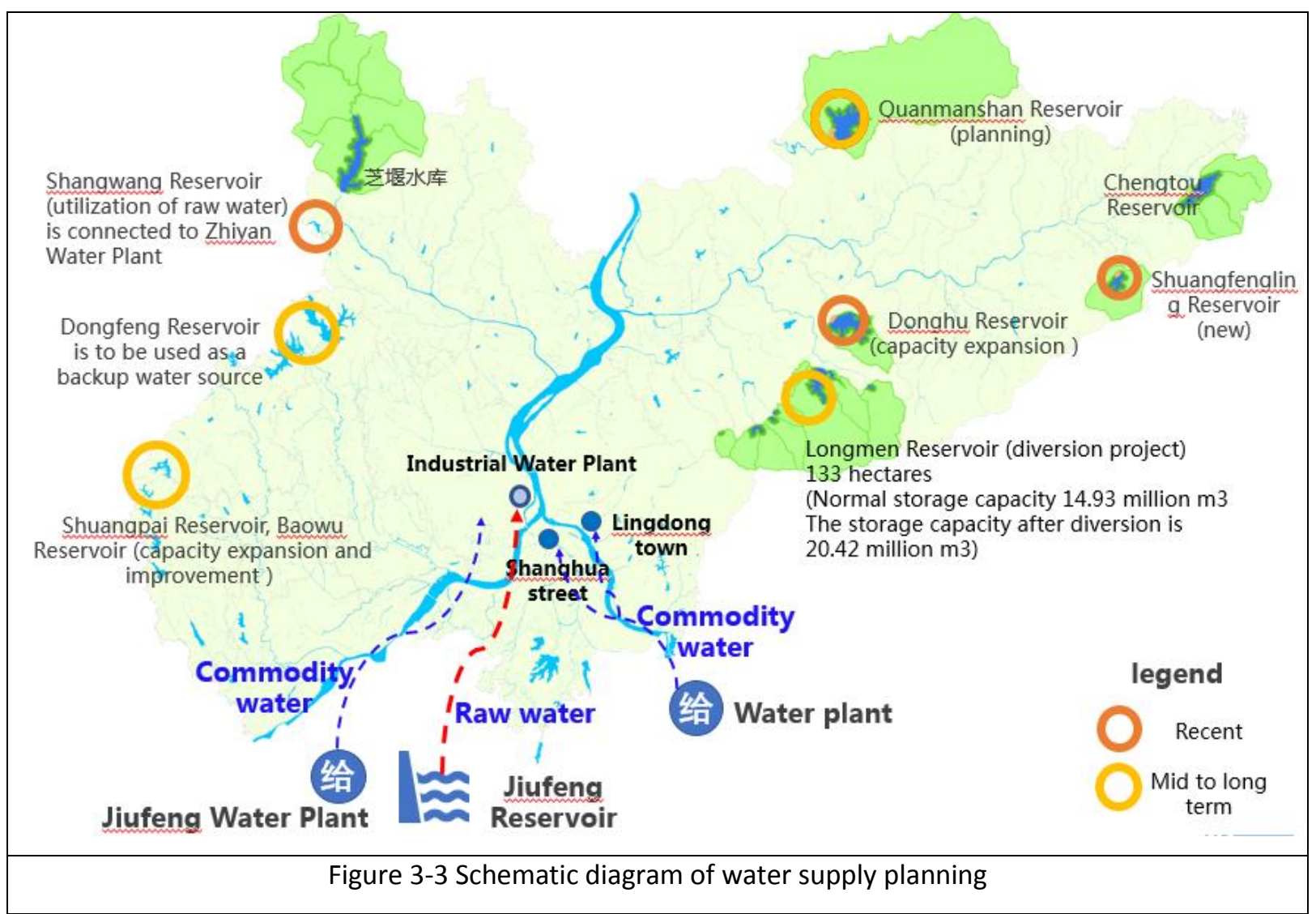

Source: self-painted by the author

\section{Building a resilient flood-bearing safety system pattern}

\subsection{Study the internal and external influencing factors of frequent flooding}

Through the analysis of the basin characteristics, climate change, rainfall and other research and analysis of the study area, it is judged that there are three reasons for the frequent occurrence of floods in the study area. First, the study area accepts a large area of catchment water in the basin and undertakes 14 times the flow of its catchment area. Second, the study area is located in an area with a high incidence of Meiyu in China, where rainfall is concentrated, with heavy rainfall and short time from June to July each year. The third reason is that as the urbanization of the river basin accelerates, changes in the surface have led to an increase in surface runoff coefficient. 


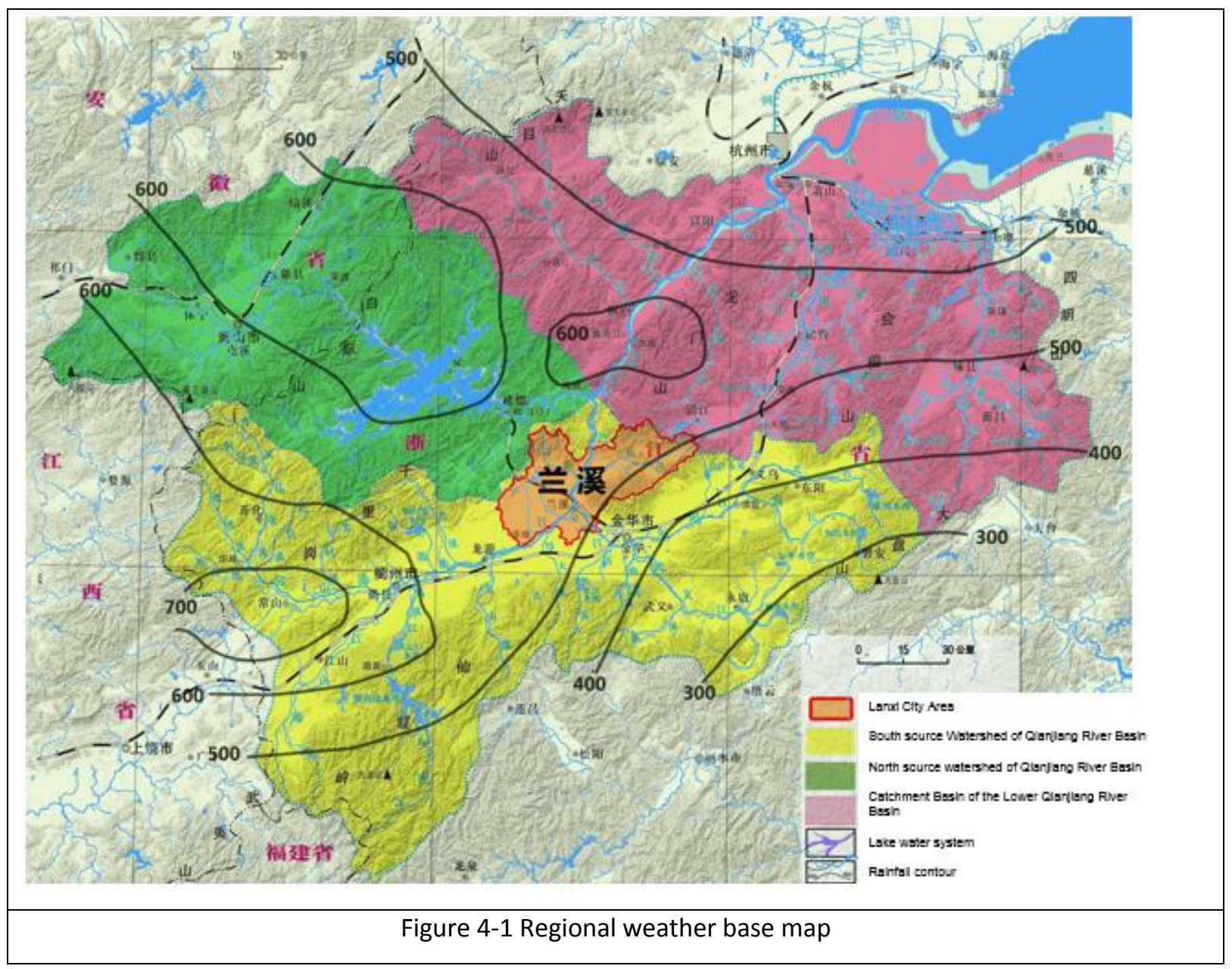

Source: self-painted by the author
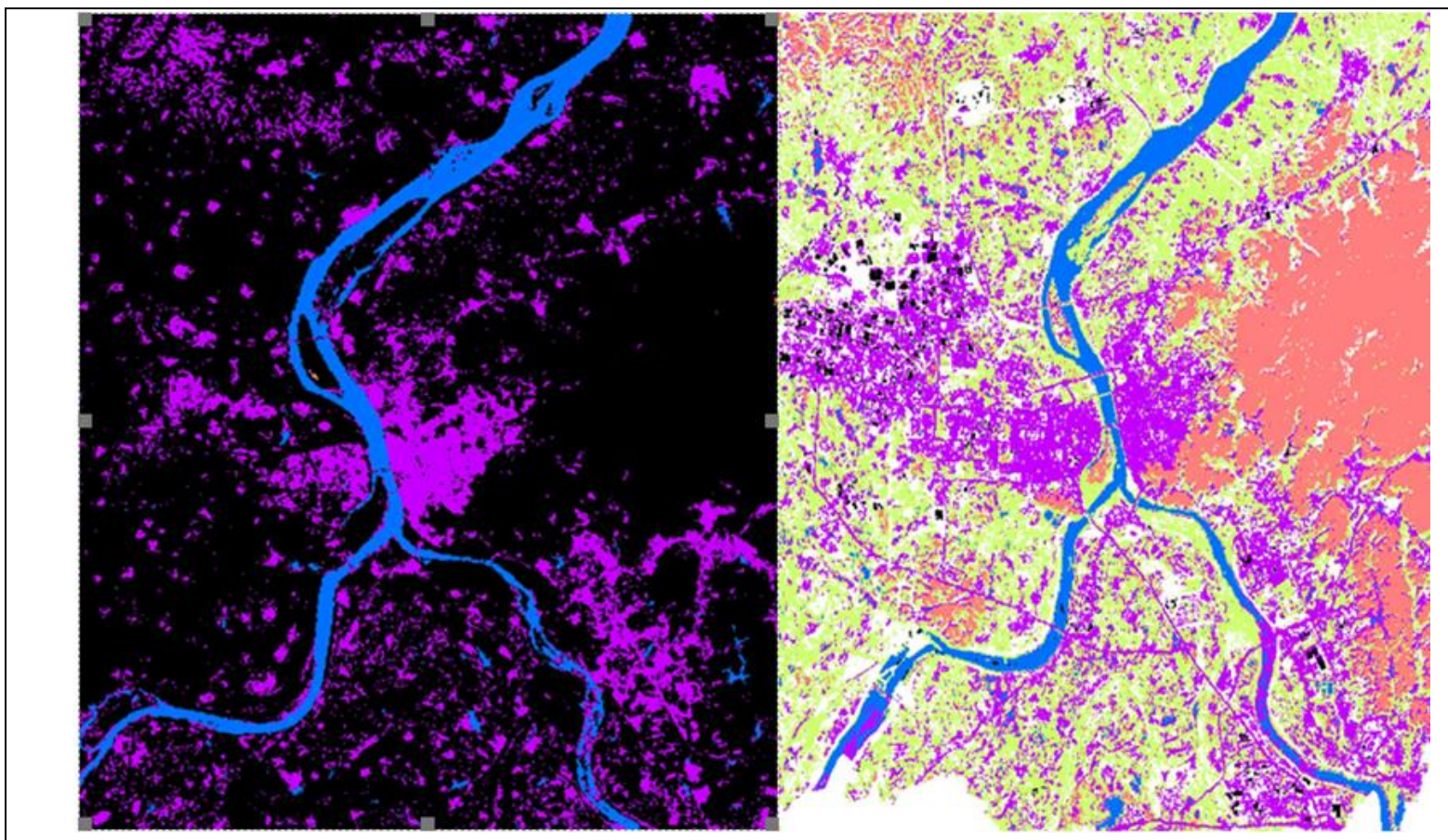

Figure 4-2 Comparison of urban construction of Lanxi in 2000 and 2018

Source: self-painted by the author 


\subsection{Comprehensive use of multiple technical methods to accurately identify and study}

\section{regional flood climate risks}

Flood climate risk assessment is an important scientific basis for the setting of flood insurance, floodplain management, flood refuge, disaster warning and assessment in a region. In this study, in order to accurately identify the flood risk in the Lanjiang Basin, scientific and technological means such as GIS and Global Mapper were used comprehensively. Integrating historical flood peak flow, flood level and other data, considering the current dike construction and urban construction, combined with regional topographic elevation DEM data and other elements, the study area flood meteorological risk is divided into four levels.

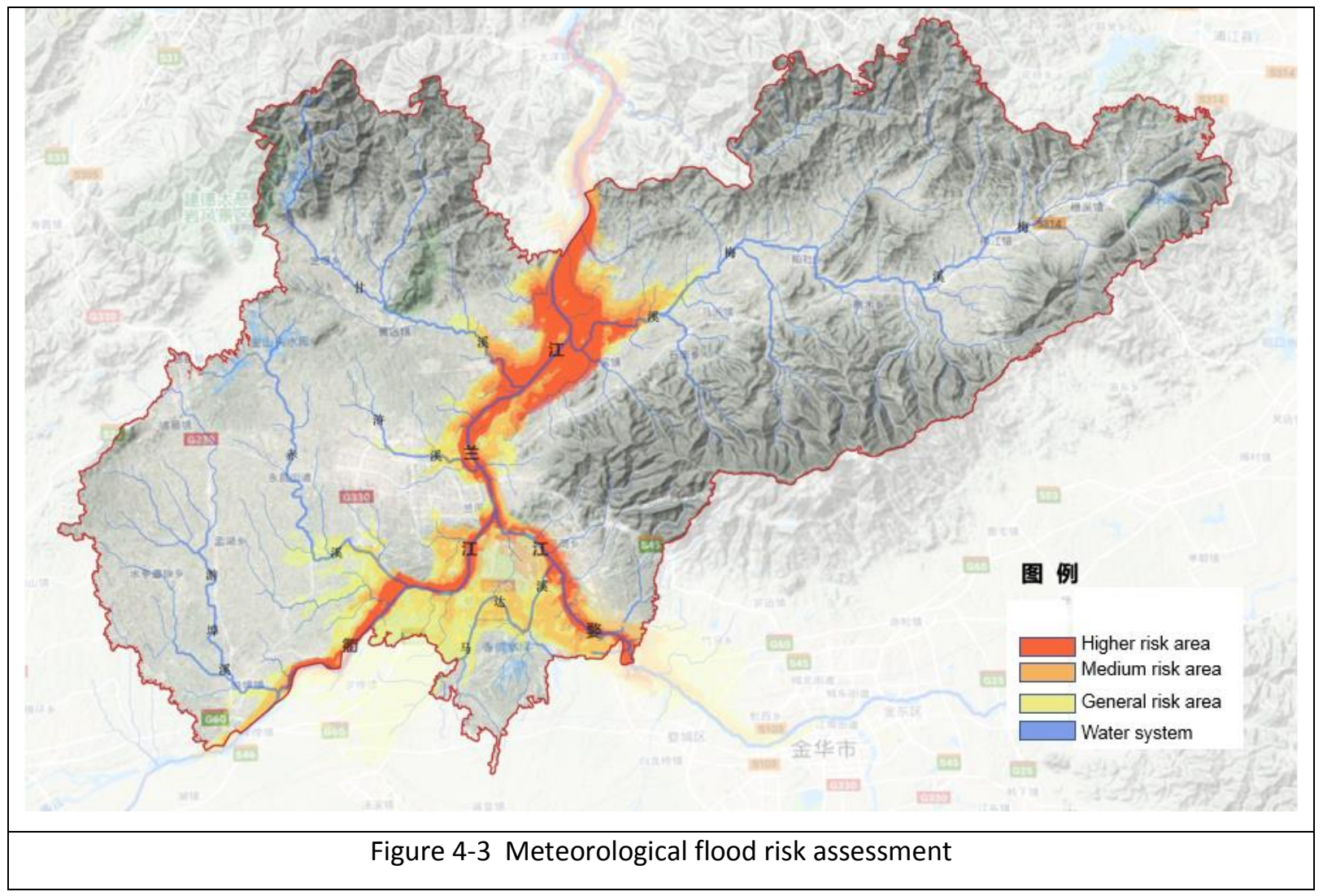

Source: self-painted by the author

\subsection{The concept of urban resilience to bear floods, "live with floods"}

In recent years, in the struggle against flood disasters, people have gradually proposed a shift from rigid flood resistance to "flood management". More and more scholars and city managers are beginning to accept the idea that "a better way than defending a river is to be with the river". To ensure urban safety is not only the construction of large-scale flood control embankments and other engineering defensive measures, but also the strengthening and restoration of floodplains, lakes, wetlands and other areas with flood regulation and storage functions.

The concept of urban resilience to floods means that cities can avoid, prepare for, and respond to urban rain and flood disasters, and are not affected by disasters or can quickly recover from them. On this basis, the flood will be used as a resource to realize the transformation from flood control to flood risk management. '[12-13】 


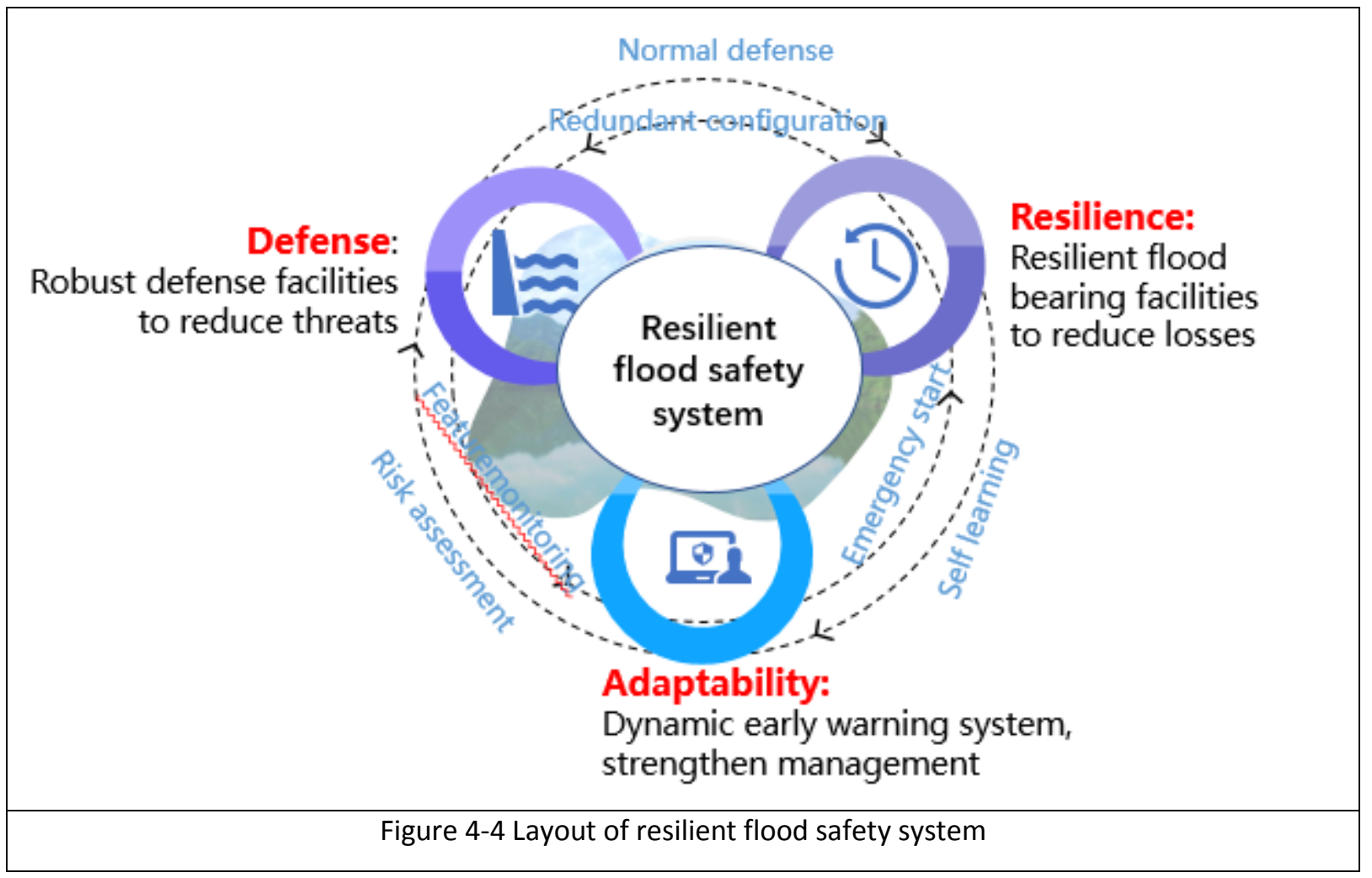

Source: self-painted by the author

\subsection{Safely resist floods---strengthen the construction of engineering facilities and improve} the city's security defense

(1) Diversified engineering water control strategies

Through an engineering water control strategy that combines "control, construction, drainage, and drainage", the Lanxi flood control and drainage system will be constructed to improve the comprehensive capacity of Lanxi flood control and drainage and deal with Lanxi flood risks.

The types of engineering facilities mainly include: water control facilities in the basin, such as flood prevention reservoirs, sluice control facilities; construction of embankment engineering facilities, repair and reinforcement of the original aging dikes; drainage and flood diversion projects, and dredging of river bayonet sections Widen, improve the flow capacity of the river, strengthen the construction of flood control enclosures and flood storage and detention areas, and enhance the short-term flood storage capacity during peak periods; drainage engineering facilities, optimize the layout of drainage pumping stations, improve drainage capacity, and strengthen intelligent drainage pumps Station application to enhance emergency response capabilities.

Set up different levels of staging areas. According to the flood characteristics and the level of flood volume, the volume of the flood diversion area is selected to minimize the loss caused by flood diversion. According to the importance of the protected area, the fortification standard of the protected area shall be approved. In combination with different forecast flood levels, the storage and stagnation area will be gradually opened according to the situation. 


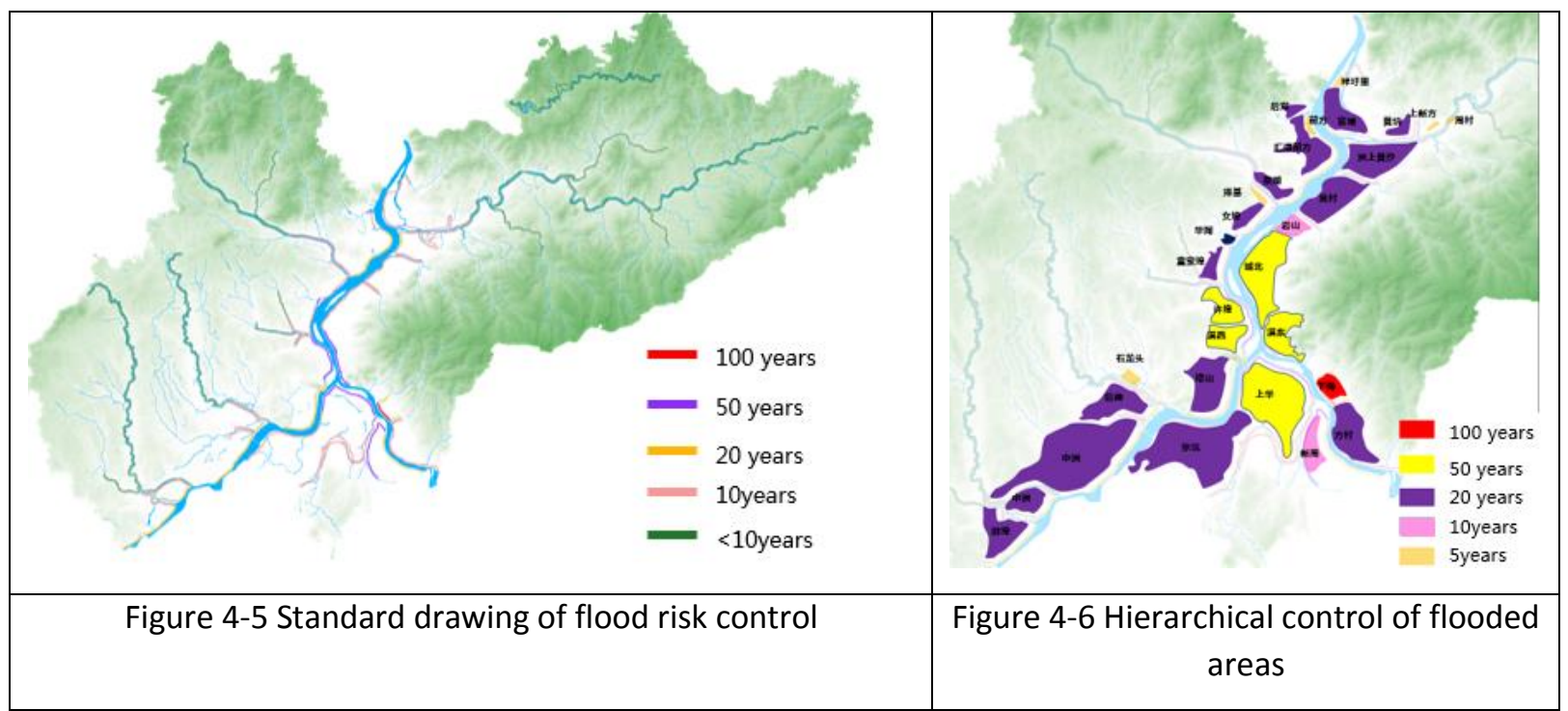

Source: self-painted by the author

(2) Strengthen the management and control of the development and construction of waterfront space

In order to ensure the necessary corridor water system space along the water system, strictly control the retreat of construction space along the river. According to the topological structure of the water system network, the construction space requirements are formulated. In order to ensure the continuity and integrity of the water space, it is achieved by delineating the water blue line. At the same time, coordinate the conflicts between water space and other types of land.

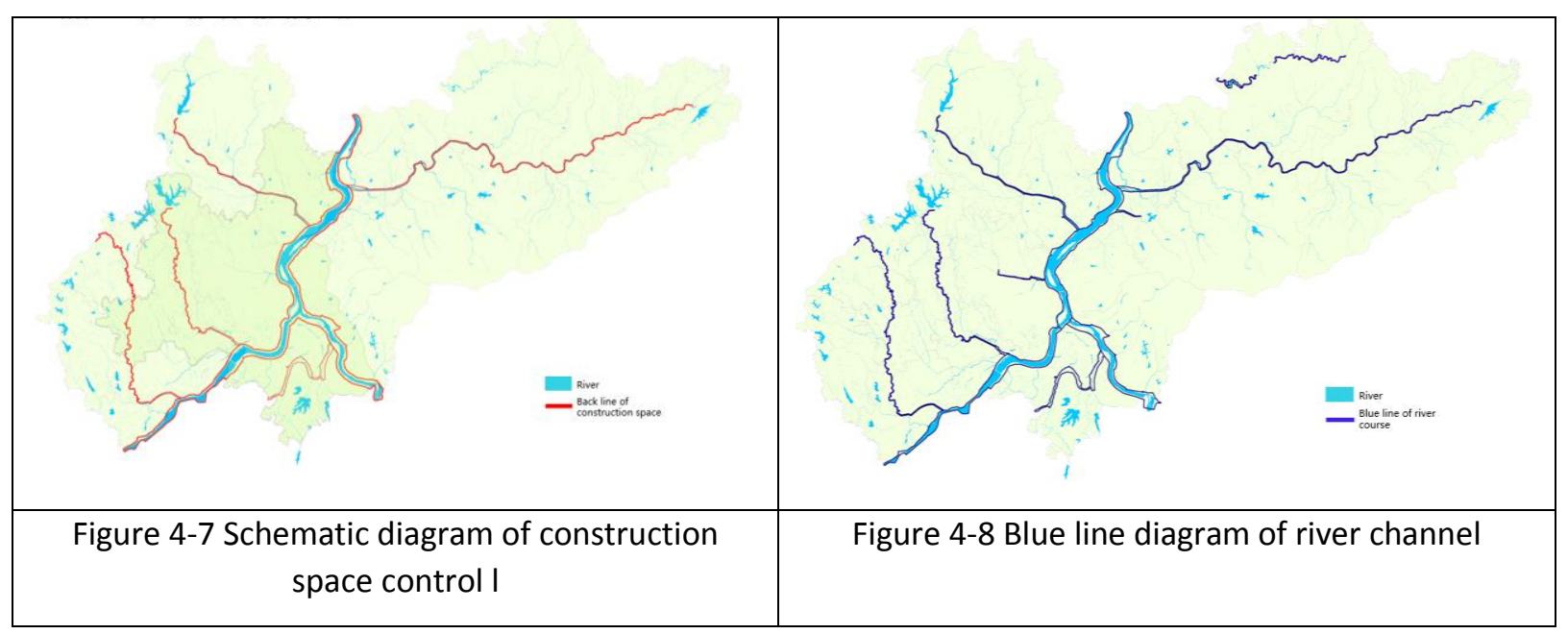

Source: self-painted by the author

(3) Construct a comprehensive management system for river basin flood control

Study the connection of flood disasters in the upper and lower reaches of the entire basin and conduct risk assessment. Based on river basin flood disaster maps and risk maps, a cross-administrative basin flood risk management system organization should be formed. Improve the city's emergency response mechanism and build a city's pre-disaster early warning, disaster response, and post-disaster recovery system. 


\subsection{Safe in floods-building multi-level resilient flood-bearing measures}

Urban resilient flooding refers to its ability to adapt to floods when it prevents damage to engineering facilities or when the set flood control standards are not sufficient to withstand flood disasters. When encountering unavoidable floods, every citizen and public administrator can respond more flexibly to floods. This study emphasizes the change from "blocking" to "sparse", and emphasizes allowing water to have a certain degree of free space. Construct resilient flood-bearing facilities from three levels: region, city, and site. Coordinate flood defense and spatial planning, and handle the relationship between resilient flood-bearing space and flood defense functions. ${ }^{[14-16]}$

Create a smooth water network system. Pay attention to the natural characteristics of the river network, follow the river network structure of the natural river system, and ensure the connection of the river network. At the same time, it emphasizes the coordination of water system network and urban construction space.

Build a variety of rainwater storage systems. Construct a complementary rain and flood regulation and storage system composed of rivers, lakes, reservoirs, and wetlands. Increase rainwater storage facilities and detention ponds in urban built-up areas to absorb and store precipitation during peak rainstorm periods. While ecological regulation and storage, it also improves the quality of the urban environment.

(1) Building a water security pattern at the regional level

Through the combination of "points, lines, and regions", the storage of rainwater is realized. From the source, use the lakes and reservoirs in the city to increase the retention of rainwater during periods of heavy rainfall. Use river corridors to increase their own ecological storage capacity and reduce rain and flood pressure. Set up a certain detention area to decompose the risk of urban rain and flood.

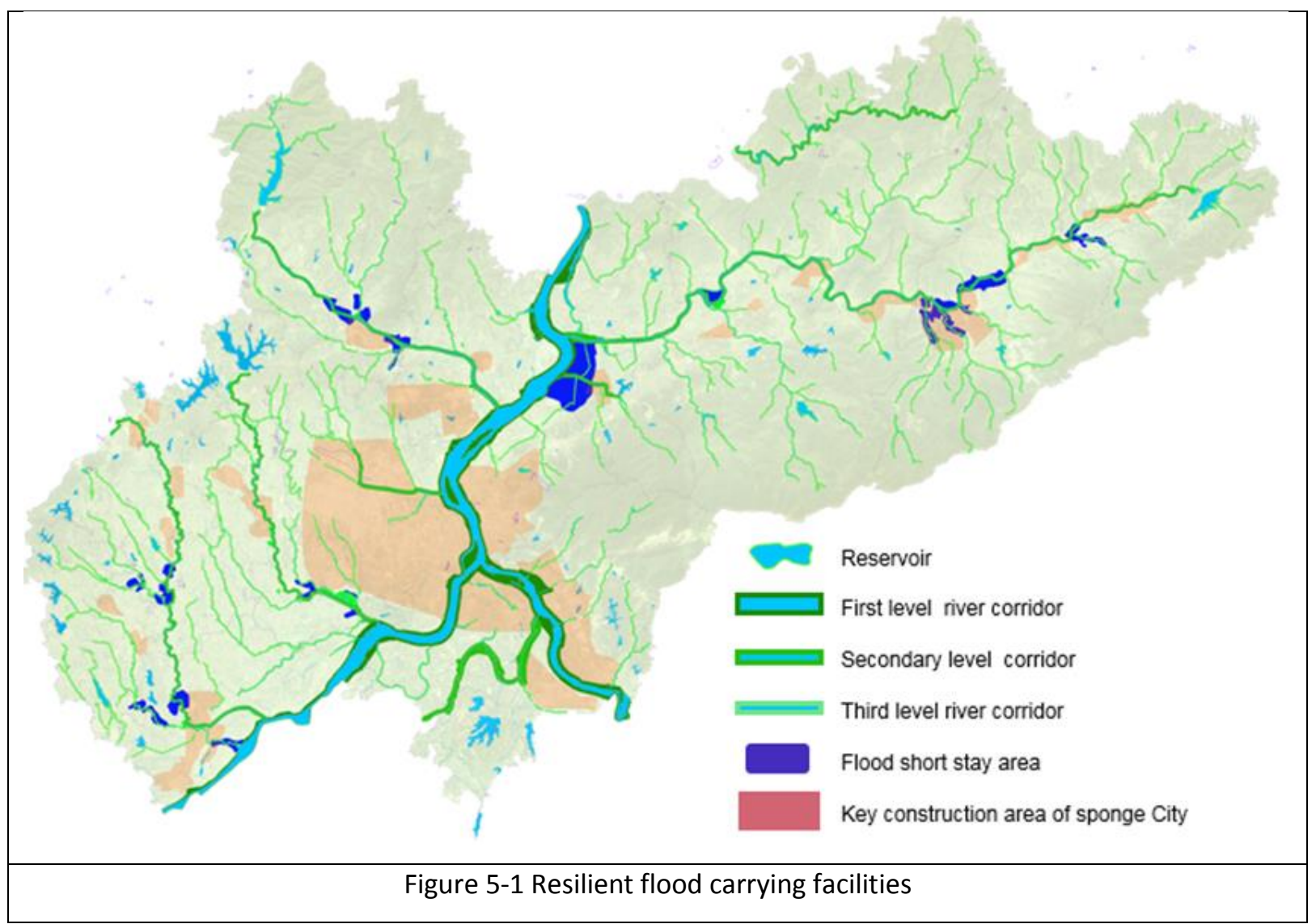

Source: self-painted by the author 
(2) Strengthen the construction of sponge cities

This research uses the construction idea of "sponge city" to solve the problem of urban waterlogging. According to the different urban characteristics of the central city, corresponding sponge city construction goals are set. According to the existing construction area and the area to be constructed, different construction priorities are distinguished. For areas that have been built, the concept of sponge city construction is injected into urban renewal, focusing on solving problems such as pipe network, rainwater pollution and rivers, and poor drainage. At the same time, we will gradually implement the transformation of sponge construction, such as the restoration of old rivers, the construction of rainwater parks, and the transformation of road sponge facilities. For new areas to be constructed, the concept of low-impact development is adopted and the original natural ecosystem is respected.

(3) Develop stormwater system control guidelines at site level

To promote the construction of sponge cities, control runoff pollution, reduce the pressure of flood control and drainage, rational use of rain and flood resources, and optimize the structure of water resources as the goal, formulate rain and flood system control guidelines. It mainly includes sinking green space and sinking depth, permeable pavement rate, green roof rate, seasonal rain storage facilities, overhead buildings at the bottom, and flood prevention walls for important infrastructure.

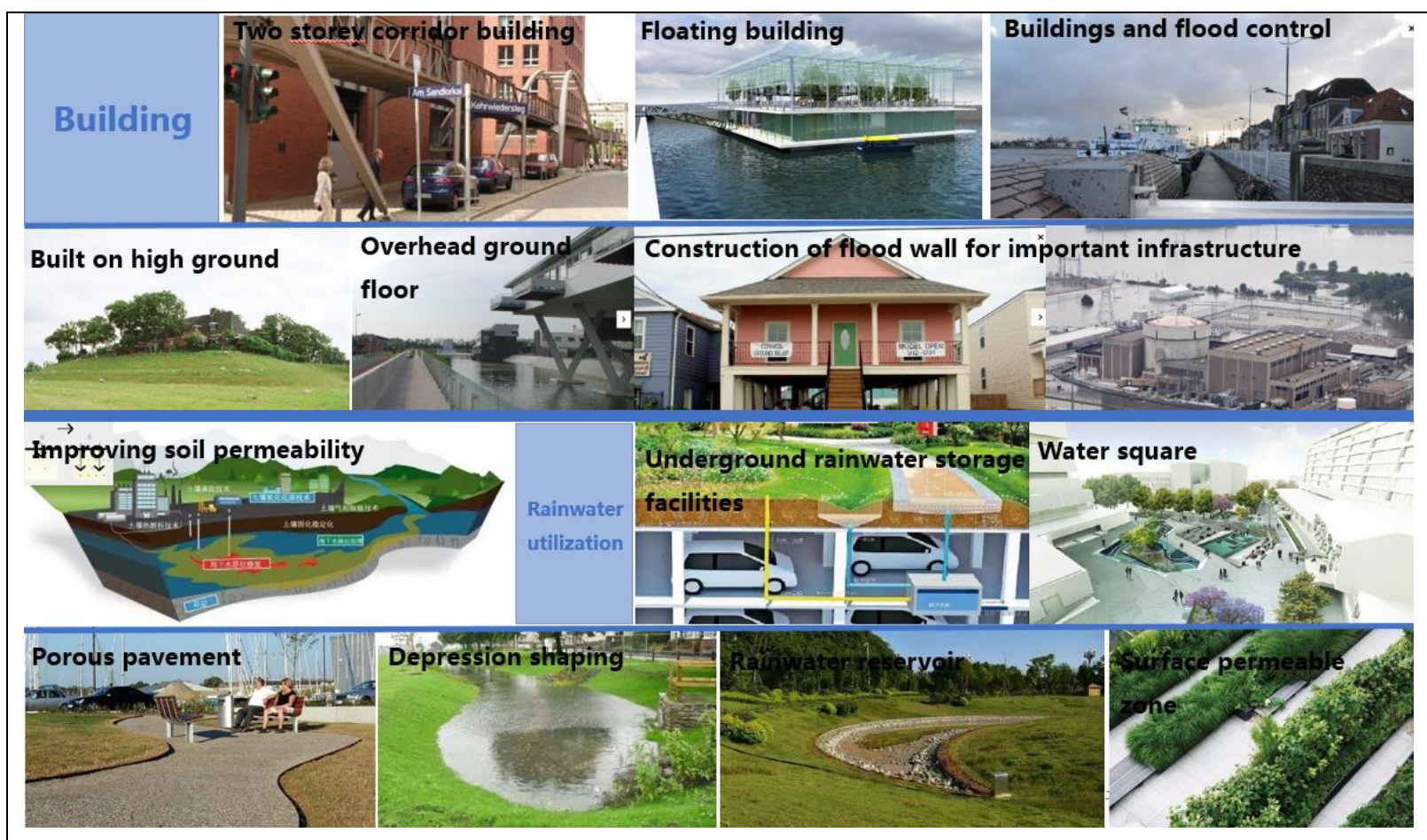

Figure 5-2 stormwater system control guidelines at site level

Source: self-painted by the author

\subsection{Dynamic risk assessment responsive planning cuts into the construction of urban}

\section{flood control system}

Integrate traditional water resources management, agricultural irrigation management, water supply and drainage planning management, water and soil conservation measures, flood prevention and disaster reduction measures, project safety operation management and other water work related monitoring data and information management methods. Establish a command center and government affairs center based on the big data platform, the information transmission network and the water Internet of Things as 
the link, and the monitoring center as the basis to establish an intelligent flood control early warning system.

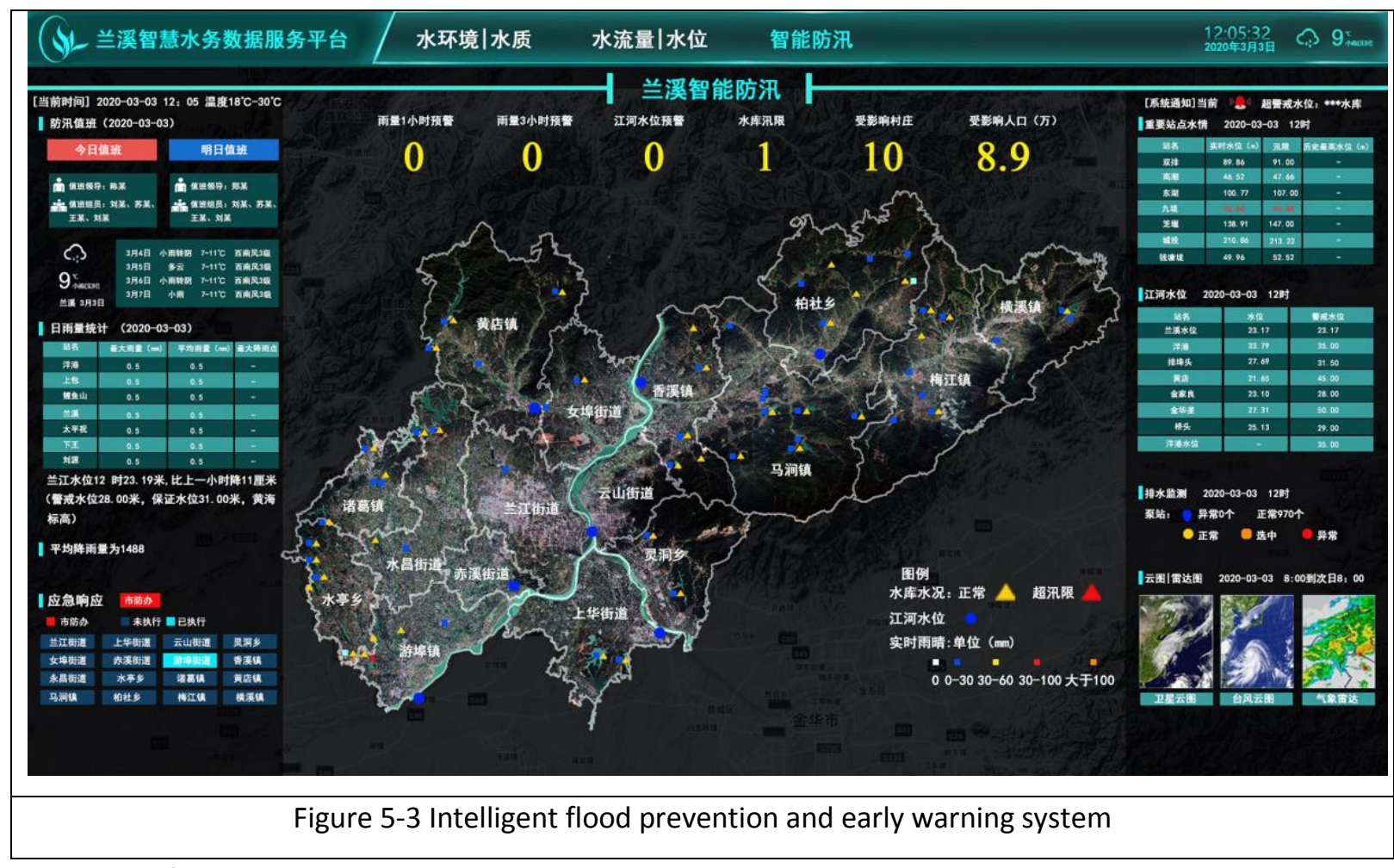

Source: self-painted by the author

\section{Conclusion}

The field of spatial planning has long focused on land areas, lacking a complete understanding of the scientific operation rules of the water system, and it is easy to ignore the basic role of the water system as the bottom of the space, causing urban and rural construction to continue to squeeze the water carrying space, and industrial development continue to lose water carrying capacity, etc. problem. From the perspective of the integration of water resources coordination and spatial planning, this research attempts to analyze and solve the spatial positioning problem of the sustainable development of water systems, and faces the more complex and changeable future human living environment changes.

\section{References}

[1]lanic Bigate Lourenço,Antonio Krishnamurti Beleño de Oliveira,Luisa Santana Marques,Amanda Andrade Quintanilha Barbosa,Aline Pires Veról,Paulo Canedo Magalhães,Marcelo Gomes Miguez. A framework to support flood prevention and mitigation in the landscape and urban planning process regarding water dynamics[J]. Journal of Cleaner Production,2020,277.

[2]E.J.C. Dupuits,W.J. Klerk,T. Schweckendiek,K.M. de Bruijn. Impact of including interdependencies between multiple riverine flood defences on the economically optimal flood safety levels[J]. Reliability Engineering and System Safety,2019,191.

[3]胡岳. 韧性城市视角下城市水系统规划应用与研究[C]//规划 60 年: 成就与挑战— 2016 中国 城市规划年会. 2016

[4]李九一,李丽娟. 中国水资源对区域社会经济发展的支撑能力[J]. 地理学报, 2012, 67(3). 
[5]刘佳骏,董锁成,李泽红. 中国水资源承载力综合评价研究[J].自然资源学报, 2011，026(2):258-269.

[6]吴生伟. 石羊河流域水资源利用的空间布局及其协调规划研究[D].兰州交通大学,2019.

[7] 黄硕俏, 吴泽宁, 狄丹阳. 水资源工业生产价值能值评估及空间分布 [J]. 南水北调与水利科 技,2020,18(01):202-208.

[8] 汪辉, 任懿璐, 卢思琪, 等. 以生态智慧引导下的城市韧性应对洪涝灾害的威胁与发生 [J]. 生态学报, 2016, 36(016):4958-4960.

[9]Gilbert F. White. Human Adjustment to Floods: A Geographical Approach to the Flood Problem in the United States[D]. University of Chicago, Department of Geography, Chicago, USA, 1942

[10]R.M.J Schielen, and G.Roovers. Adaptation as a Way for Flood Management[C/OL]//Proceedings of the 4th International Symposium on Flood Defence: Managing Flood Risk, Reliability and Vulnerability. Toronto, Ontario, Canada, May6-8,2008.

[11]Folke C. Resilience: The Emergence of a Perspective for Social-Ecological Systems Analyses[J/OL]. Global Environmental Change, 2006(16): 253-267. http://dx.doi.org/10.1016/j.gloenvcha.2006.04.002

[12] 徐耀阳,李刚,崔胜辉, 许义平, 潘军标, 童宁军, 徐继荣, 朱永官.韧性科学的回顾与展望: 从生态理论 到城市实践[J].生态学报,2018,38(15):5297-5304.

[13]Holling C S. Resilience and stability of ecological systems[J].Annual Review of Ecology and Systematics, 1973(4): 1-23.

[14]Gemma Schuch,Silvia Serrao-Neumann,Edward Morgan,Darryl Low Choy. Water in the city: Green open spaces, land use planning and flood management - An Australian case study[J]. Land Use Policy,2017,63.

[15]俞孔坚, 许涛, 李迪华, 等. 城市水系统弹性研究进展[J]. 城市规划学刊, 2015(1)：81-89.

[16]韩·梅尔, 周静, 彭晖. 荷兰三角洲：寻找城市规划和水利工程新的融合[J]. 国际城市规划, 2009(2) : 4-13 .

[17]吴志强,冯凡,鲁斐栋,杨婷,甘惟.城市韧性空间设计[J].时代建筑,2020(04):84-89.

[18]王芳,刘小梅.海绵城市建设与河道综合治理模式探讨[J].水利规划与设计,2016(06):1-4+79. 